\title{
NONINVASIVE PRENATAL TESTING: THE ASPECTS OF ITS INTRODUCTION INTO CLINICAL PRACTICE
}

Korostin DO',2凶, Plakhina DA², Belova VA ${ }^{1,2}$

${ }^{1}$ Pirogov Russian National Research Medical University, Moscow, Russia

2 Genotek Ltd., Moscow, Russia

The last couple of years have witnessed the rapid development of prenatal molecular-based screening for fetal aneuploidies that utilizes the analysis of cell-free DNA circulating in the bloodstream of a pregnant woman. The present review looks at the potential and limitations of such testing and the possible causes of false-positive and false-negative results. The review also describes the underlying principles of data acquisition and analysis the testing involves. In addition, we talk about the opinions held by the expert community and some aspects of legislation on the use of noninvasive prenatal testing (NIPT) in clinical practice in the countries where NIPT is much more widespread than in Russia.

Keywords: NIPT, NIPS, prenatal screening, fetal aneuploidy, cell-free DNA

Acknowledgment: the authors are grateful for Ekaterina Shubina of Kulakov National Medical Research Center for Obstetrics, Gynecology and Perinatology for her valuable feedback.

Author contribution: Korostin DO conceived the review and supervised manuscript preparation; Plakhina DA wrote the sections about cell-free DNA and the regulatory legislation and helped to revise the manuscript; Belova VA wrote the sections about MPS-aided NIPT and the regulatory legislation and helped to revise the manuscript.

$\triangle$ Correspondence should be addressed: Dmitry O. Korostin Nastavnichesky per. 17, str. 1, Moscow, 105120; d.korostin@gmail.com

Received: 05.10.2018 Accepted: 10.05.2019 Published online: 22.05.2019

DOI: $10.24075 /$ brsmu.2019.036

\section{НЕИНВАЗИВНЫЙ ПРЕНАТАЛЬНЫЙ МОЛЕКУЛЯРНЫЙ СКРИНИНГ: ОСОБЕННОСТИ ВНЕДРЕНИЯ В КЛИНИЧЕСКУЮ ПРАКТИКУ}

\author{
Д. О. Коростин ${ }^{1,2}$, Д. А. Плахина², В. А. Белова ${ }^{1,2}$ \\ ${ }^{1}$ Российский национальный исследовательский медицинский университет имени Н. И. Пирогова, Москва, Россия \\ 2 ООО «Генотек», Москва, Россия
}

\begin{abstract}
Развитие пренатального молекулярного скрининга анеуплоидий плода, основанного на анализе внеклеточной ДНК, циркулирующей в крови беременной, происходит бурно, особенно в последние 2-3 года. В обзоре представлены возможности и ограничения использования этой методики в клинической практике, а также причины ложноположительных и ложноотрицательных результатов скрининга. Описаны принципы, лежащие в основе технологий как получения, так и анализа данных. Рассмотрены мнения профессиональных сообществ, а также особенности законодательного регулирования применения неинвазивного пренатального скрининга (НИПС) в клинической практике в странах, где уровень использования НИПС существенно превышает отечественный.
\end{abstract}

Ключевые слова: NIPT, НИПС, пренатальный скрининг, анеуплоидии плода, внеклеточная ДНК

Благодарности: авторы очень признательны сотруднице ФГБУ «НМИЦ АГП имени В. И. Кулакова» Екатерине Шубиной за ценные замечания и рекомендации, которые она давала в ходе подготовки обзора.

Информация о вкладе авторов: Д. О. Коростин — идея и план публикации, общее руководство подготовкой публикации; Д. А. Плахина — подготовка разделов о внДНК и о законодательстве, редактирование рукописи; В. А. Белова - подготовка разделов о НИПС с помощью МРS, подготовка раздела о законодательстве, редактирование рукописи

$\triangle$ Для корреспонденции: Дмитрий Олегович Коростин Наставнический переулок, д. 17, к. 1, г. Москва, 105120; d.korostin@gmail.com

Статья получена: 05.10.2018 Статья принята к печати: 10.05.2019 Опубликована онлайн: 22.05.2019

DOI: $10.24075 /$ vrgmu.2019.036

Fetal chromosomal aneuploidy is one of the primary causes of spontaneous abortion, accountable for $35 \%$ of all miscarriages [1] and occurring in $0.3 \%$ of all births [2, 3]. The most common aneuploidies are trisomies 13, 18, 21 and XXY.

Trisomy 21 , or Down syndrome (DS), is observed in 1 in 800 births [4]. The risk of fetal DS increases with maternal age, starting to grow exponentially once a woman turns 34 and approximating an incidence rate of 1 case per 35 births in women over 40 [5].

Until the 1980s, a woman's age was the only reliable prognostic criterion for the risk of aneuploidy; all pregnant women over 35 were recommended to undergo an invasive diagnostic test aimed to identify the karyotype of the fetus. For younger women, the only indication for invasive diagnostic procedures was a family history [6].

Today, the 1st trimester combined ultrasound and biochemical screening test proposed back in 1997 [7] is considered to be the most reliable prognostic tool with its sensitivity of $90 \%$ for Down syndrome and the false positive rate of 5\% [8].

At present, only invasive diagnostic techniques are employed to diagnose hereditary pathologies of the fetus, including chorionic villus and amniotic fluid sampling. The obtained specimens of fetal cells are analyzed by QF-PCR, MLPA, G-banding, FISH, and molecular karyotyping [9].

\section{Origin of cell-free fetal DNA}

Cell-free fetal DNA (cffDNA) transcends the placental barrier and enters the maternal bloodstream [10]. Modern technologies can detect cffDNA in the maternal blood plasma as early as the 4th week of gestation. Its concentration increases throughout pregnancy, peaking in the last 8 weeks before delivery and then dropping abruptly to almost 0 in the first hours after birth [11-15]. Cell-free fetal DNA originates in the placental trophoblast and 
leaks into the maternal bloodstream following the apoptosis of trophoblast cells [16]. The placental origin of cffDNA is corroborated by its presence in anembryonic pregnancies in which no embryo is formed, but placental tissue is in place [17], as well as in women with meiotic placental mosaicism (PM).

PM, which is essentially a discrepancy between the karyotypes of a fetus and a maternal placenta, strikes 0.6-1\% of women who previously underwent invasive diagnostic procedures [18]. PM can be broken down into mitotic and meiotic types. Mitotic PM results from the chromosoma nondisjunction during one of the divisions of a diploid zygote that gives rise to an aneuploid cell line and leads to confined PM. As a rule, confined PM affects only a limited region of the placenta and can be defined as a low-level mosaicism. Meiotic PM originates from an initially trisomic zygote in which a rescue event occurs: the loss of an extra chromosome copy in the early stages of fetal development. Thus, even if the placenta is partially or fully aneuploid, the fetus can still have a normal karyotype, and vice versa.

\section{Cell-free fetal DNA characteristics}

Cell-free DNA molecules circulating in the maternal blood are chopped fragments of $166 \mathrm{bp}$ (maternal cfDNA) or $143 \mathrm{bp}$ (fetal cfDNA) in length [19]. Such size distribution is the result of nonrandom DNA fragmentation [20]. DNA is degraded by various enzymes that cut at the sites they can access. Nucleosomes represent the first level of DNA compaction. They are histone spools with DNA wound around them, spaced 20 base pairs apart. These linker regions can be easily accessed by nucleases. Therefore, we can assume that a 143 bp-long cffDNA fragment corresponds to a "linkerless" DNA coil wound around a nucleosome, whereas a 166 bp-long maternal cfDNA fragment corresponds to a DNA coil containing a linker region. The nonrandom fragmentation pattern can be explained by the difference in histone $\mathrm{H} 1$ isoforms determined by the placental or hematopoietic origin of nucleosomes. The main function of histone $\mathrm{H} 1$ is to bind to a linker; apparently, the binding does not occur in the case of cffDNA, and the linker is chopped off [19, 21].

The "sawtooth"-like size distribution of shorter DNA fragments with a peak periodicity of $\sim 10$ bp suggests that cellfree DNA undergoes further nuclease cleavage in apoptotic bodies at the position of approximately every 10th nucleotide directly attached to a histone protein $[19,22]$. No similar size distribution is observed during the analysis of short reads mapped onto a mitochondrial genome that lacks histones.

It has been established that hypo- and hypermethylated regions of fetal and placental genomes do not match those of the maternal genome because of epigenetic difference between tissues $[23,24]$. It is hypothesized [25] that unmethylated DNA regions are more accessible for cutting. Maternal cfDNA is hypermethylated, which means tighter DNA wrapping around histones, increased compaction and nucleosome stability, and longer average cfDNA fragment lengths in comparison with fetal DNA.

\section{NIPT aided by MPS}

Fetal cells, fetal cell-free RNA and fetal cell-free DNA are potential targets for liquid biopsy. Fetal cell-free DNA has a number of advantages that allow it to be used as a basis for noninvasive prenatal testing (NIPT).

On average, the fetal fraction amounts to $10 \%$ of total cell-free DNA at the gestational age when prenatal testing is performed. This value exceeds the number of fetal cells circulating in the maternal blood by $3-4$ orders of magnitude.
The contribution of maternal microchimerism is normally negligible in comparison with the fetal DNA fraction. Cell-free DNA is more stable than cell-free RNA, and the methods used for its analysis are better reproducible.

NIPT can be described as a statistical examination aimed at estimating how well each chromosome is represented in a studied sample. Normally, the number of short reads per each chromosome of a nonpregnant woman is proportional to the length of this chromosome. The same is true for women who carry a child with a normal karyotype. However, in trisomies, as is the case with trisomy 21 , the proportion of reads needed to cover all copies of the chromosome of interest will be increased relative to other chromosomes. The length of chromosome 21 amounts to about 1.5\% of the entire genome. Given that the cffDNA fraction makes $10 \%$ of total cfDNA present in the sample, the extra chromosome 21 will cause a $0.08 \%$ rise in this value. To assess the reliability of NIPT results, different statistical methods are used, the most common being Fisher's $Z$ test. It is employed to investigate whether an increase in the read count per chromosome of interest is accidental. The actual coverage is compared to the expected precalculated value with due account of the standard error. $Z$ is calculated by the formula:

$$
Z=(x-\mu) / \delta,
$$

where $\mathrm{A}$ is the studied chromosome; $x$ is the number of reads mapped to $A$ in the analyzed sample; $\mu$ is the mean read count needed to cover $A$ in the reference sample (normal control); $\delta$ is the standard deviation. The resulting $Z$ score $>3$ suggests trisomy; $Z<-3$ suggests monosomy, whereas a range of values from -3 to 3 are indicative of a normal karyotype [26].

The expected value is calculated based on the analysis of a cell-free DNA sample obtained from a diagnosed child.

During the analysis, maternal cfDNA is not separated physically from fetal DNA. This means that if a woman carries multiples, NIPT will be able to detect aneuploidy but will not point to the affected fetus.

NIPT outcomes are largely determined by the fetal DNA fraction. The higher is the proportion of fetal DNA, the higher is the $Z$ value yielded by the analysis in the case of aneuploidy. The minimum fetal fraction needed for reliable NIPT results is $4 \%$ [27-29].

Although methods for estimating the proportion of fetal DNA vary, they all share the same underlying principle, searching for significant differences between fetal and maternal cell-free DNA fractions. Such differences involve the presence of $Y$ chromosome, which amounts to half of total cell-free DNA. This approach, however, can only be applied to women carrying male fetuses.

The universal and widespread SNP-based approach to estimating the fetal DNA fraction exploits a simple idea: one should look for those polymorphic loci where the mother is homozygous and the baby is heterozygous (due to the presence of the paternal allele). The polymorphic regions should be sequenced multiple times, and then the number of reads covering the paternal allele should be counted [30-32]. The cffDNA fraction is then calculated by multiplying the proportion of such reads by 2 . The following criteria are applied to SNP selection:

- minor allele frequency (MAF) of about 50\%;

- SNP should be constituents of different linkage groups;

- SNP should not be under natural selection pressure.

By expanding the panel of target SNPs, one can even detect aneuploidies through comparing read counts per fetal and maternal polymorphic loci in a chromosome of interest. This idea was adopted by Natera to design a noninvasive prenatal test based on the analysis of almost 20,000 SNP [33]. 
Fetal DNA fraction can also be reliably estimated by calculating the proportion of differentially methylated genome regions in the analyzed cell-free methylome [34].

Because the lengths of fetal and maternal DNA molecules are distributed nonuniformly, the fetal DNA fraction can be determined from the ratio of fragments sized 100-150 bp to those sized 163-169 bp, since they correspond to the fetal and maternal DNA fractions, respectively [35]. This approach is effective in paired-end sequencing [36].

Another novel "nucleosome track" method of quantifying the fetal DNA fraction is underway. The idea behind it is that fetal DNA fragmentation is not random and follows a certain pattern determined by DNA packaging into nucleosomes, as described above [37].

Researchers are also starting to harness neuronal networks to estimate the fetal DNA fraction. Using large training samples (thousands of specimens with a known fetal DNA fraction), one can get reliable results by analyzing a number of certain sequencing parameters [38].

\section{NIPT potential}

NIPT is mostly used to screen for chromosomal aneuploidies, but massively parallel sequencing (MPS) technologies are capable of detecting other genome abnormalities as well.

Low and ultra-low $(<\times 1.0)$ coverage genome sequencing does not allow point mutations to be detected, but can be employed to screen for deletions and duplications [39]. Such strategy is used to perform prenatal genetic screening aided by high-throughput sequencing [40]. In most cases, NIPT data resolution is not sufficient to capture medium-sized (up to 5 billion bp) deletions and duplications; this problem can be solved by improving data yield per studied sample [41-44]. Unfortunately, this adds to the costs of testing. More complex bioinformatic methods of data processing are a bit less effective $[45,46]$. The amount of sequencing data yielded from the sites of interest can be significantly increased through targeted enrichment of genomic DNA regions. For example, the Panorama test [47] targets about 20,000 polymorphic loci densely located in the regions prone to microdeletions. The developers believe that the detection accuracy of the test is $97.8 \%$ or higher [48]

Since the moment cffDNA was discovered, the world has seen the emergence of various approaches to the diagnosis of genetic abnormalities of the fetus. The very first of them were capable of determining the sex of the fetus [49] and its Rh factor [50]; they were designed to screen for the sequences that do not typically occur in the maternal genome and exploited different PCR types, including $\mathrm{gPCR}$, ddPRC, and QF-PCR. Later, the development of methods for detecting genetic traits inherited from the father became a routine practice: X-STR markers [51], markers of autosomal dominant conditions, such as Huntington's disease [52] and myotonic dystrophy [53] were soon discovered. However, the majority of monogenic diseases are autosomal-recessive and their development is driven by the mutations in both maternal and paternal copies of the genome. Because of that, prenatal screening typically includes 3 sequencing procedures: sequencing of maternal and paternal genomic DNA required to identify parental haplotypes and locate the mutations of interest followed by cfDNA sequencing in order to see what chromosomes the baby has inherited [54].

The analysis of the cffDNA methylome has revealed the pattern of methylation that can serve as an aneuploidy marker $[55,56]$. It has been shown that the placental methylome, which is what NIPT analyzes, is dynamic; the methylation pattern can change depending on the condition of the fetus and the mother. For example, the analysis of cfDNA methylation can be used to diagnose preeclampsia [57-59].

Although there are a few disadvantages to using cellfree RNA as an analyte in screening tests (contamination by noninformative rRNA, poor preservation in the sample, low reproducibility of test results in comparison with cfDNA), changes in the expression of some RNA transcripts in the fetus can be a reliable predictor of preeclampsia long before a woman develops its symptoms [60].

\section{NIPT validation}

Like any other diagnostic technique, NIPT had to undergo clinical trials to prove its efficacy.

In 2014, a study conducted in 1,914 pregnant women from 21 US medical centers demonstrated that for NIPT the false-positive rate was significantly lower than for the standard biochemistry screening (0.3\% vs. 3.6\%, $p<0.001$ for trisomy 21 and $0.2 \%$ vs. $0.6 \%, p<0.03$ for trisomy 18$)$. The test failed in $0.9 \%$ of the participants [61].

A study published in 2015 compared the efficacy of NIPT with that of conventional diagnostic techniques [62]. It was conducted in 35 medical centers using the samples collected from 15,841 pregnancies. NIPT was able to detect all cases (38) of true aneuploidy in patients with fetal trisomy 21; in 9 patients the results were false-positive. For trisomy 21 , DR was $100 \%$, FPR was $0.06 \%$, and PPV was $80.9 \%$ (the standard screening test used in the study returned $78.9 \%, 5.4 \%$, and $3.4 \%$ for DR, FPR and PPV, respectively). NIPT performance was significantly better than that of standard screening in pregnant women with fetal trisomies 13 and 18. This means that NIPT can be used for detecting fetal trisomies in the clinical setting because it has better resolution and higher accuracy in comparison with conventional diagnostic tools.

\section{Causes of false-positive results in NIPT}

NIPT has a number of limitations that can cause false-positive results.

\section{Maternal weight and gestational age}

The amount of cffDNA correlates positively with the gestational age and is reversely proportional to the body mass index of a pregnant woman. Too few cffDNA fragments at 9-10 weeks into pregnancy do not allow NIPT results to be reliable. For women with high BMI, the test can turn to be ineffective as well, because the probability of a false-positive result remains high $[15,63]$ if cffDNA fraction is not estimated.

\section{Placental mosaicism}

Women who tested positive for aneuploidy by NIPT are advised to undergo an invasive diagnostic procedure to rule out placental mosaicism. Here, amniocentesis should be preferred over chorion villus sampling because the DNA in the villi has the same placental origin as cffDNA [64-67]. It is absolutely not recommended to base the decision of pregnancy termination on NIPT results solely (see below).

\section{Twins}

Although NIPT can detect aneuploidies in twin pregnancies, it is unable to identify which of the twins has a chromosomal abnormality. Here, invasive diagnostic techniques should be 
employed. Despite the fact that the total cffDNA fraction is higher than in singleton pregnancies [68] and it is possible to estimate the fetal fraction for each of the twins, the accuracy of NIPT is lower than in the case with singleton pregnancies [69].

A vanishing twin syndrome occurs in multiple pregnancies when one of the fetuses dies in the first trimester. The frequency of aneuploidies among vanishing twins is higher than in healthy twins. Because NIPT analyzes total cell-free DNA and in the majority of cases cannot detect the presence of additional haplotypes in the samples, a vanishing twin can contribute to false-positive test results, being an aneuploid fetus itself; it can also mask the aneuploidy of the second twin, causing false-negative results and interfering with sex determination. The study that analyzed data yielded by over 30, 000 noninvasive prenatal tests demonstrates that vanishing twins with aneuploidies occur in $0.11 \%$ of the total sample [70]. This is quite close to the false-positive rate reported by an extensive meta-analysis of the literature on NIPT [71]. To avoid errors associated with vanishing twins and to timely detect the second fetus, ultrasound examinations performed in the 1st trimester should be more meticulous.

\section{CNV in parents}

It is reported that $17 \%$ of all false-positive NIPT results are associated with CNV 0.5 to 14 billion bp in size present in maternal cells [72].

Just like placental mosaicism, parental mosaicism can skew test results. For example, the frequency of monosomy $X$ directly correlates with a woman's age [74]; $16 \%$ of sex chromosome aneuploidies detected by NIPT are linked to the abnormalities of the maternal chromosome $X$ [65]. The frequency of monosomy $X$ varies from $1: 3,300$ (the proportion of mosaic cells is above 34\%) [74] to $1: 300$ (the proportion of mosaic cells is $4 \%$ and above) [75], depending on the low detection threshold for mosaicism.

\section{Tumors}

NIPT results can be unreliable in pregnant women with cancer because cancer cells have an unstable genome, tumors usually produce a vast network of blood vessels and release a lot of cfDNA into the bloodstream [76].

\section{Myths about the dangers of invasive diagnostic tests}

Among the arguments for a more vigorous clinical promotion of NIPT lobbied by NIPT manufacturers is the risk of complications (including pregnancy loss) associated with invasive diagnostic tests: both amniocentesis and chorionic villus sampling are reported to result in pregnancy loss in $1 \%$ of cases $[4,77,78]$. However, other authors provide different figures on pregnancy loss following an invasive diagnostic porcedure: $1: 200$ for chorionic villus sampling and 1 : 300 for amniocentesis [79, 80]. These values are lower than the rate of spontaneous abortions [81].

\section{Legislation and guidelines for NIPT}

At present, there are two major models of NIPT incorporation into clinical practice practiced in many countries.

1. The cohort model: the test is recommended to women at risk based on the results of a 1st trimester screening procedure. In this case, the expenses are fully or partially covered by the federal budget.

2. The commercial model: the test is offered to those pregnant women who can afford it (personal funds or health insurance).

At the moment, vast TRIDENT-2 studies are being carried out in Holland and Denmark to investigate the aspects of NIPT introduction in clinical practice (http://www.meerovernipt.nl); the participants are offered to undergo NIPT instead of 1st trimester screening tests.

Below we provide examples of how NIPT is used in different countries and talk about the regulatory legislation.

\section{United Kingdom}

In the UK, 800,000 pregnancies are reported annually. In January 2016, the National Screening Committee operating in the UK [82] recommended to incorporate NIPT into the Fetal Anomaly Screening Program [83]. The guidelines suggest that NIPT should be offered to all women at a high risk for aneuploidy (>1:150) revealed by a combined ultrasound and biochemistry test between weeks 10 and 14 of pregnancy. The efficacy report will be released in 2018-2019. If the test proves to be effective, the number of invasive screening procedures will be reduced and the saved money will be used to subsidize NIPT.

\section{Sweden}

In Sweden, 120,000 pregnancies are reported annually. In June 2016, the Swedish Society of Obstetrics and Gynecology issued guidelines [84] recommending NIPT to all women whose risk for aneuploidies inferred from the combined ultrasound and biochemistry test ranges between $1: 51$ and $1: 1,000$ and to those who cannot undergo an invasive diagnostic procedure because of HIV or hepatitis. Caution should be exercised when ordering NIPT for a woman carrying multiples. A high risk for aneuploidy means that invasive diagnostic tests should be performed, whereas for women at low risk standard checkup examinations would be enough. The Society does not recommend NIPT to every pregnant woman because there is no sufficient evidence of the test's efficacy in every cohort of pregnant patients and because of its high costs.

\section{France}

In France, the number of annual pregnancies reaches 800,000 . The French Ministry of Health issued its guidelines for prenatal testing in 2017 [85]. Before the advent of NIPT, screening

Table. Leading US manufacturers of commercial NIPT

\begin{tabular}{|c|c|c|}
\hline NIPR trade name & Manufacturer & Location \\
\hline MaterniT21Plus $^{\mathrm{TM}}$ & Sequenom, subsidiary of LabCorp, Inc. & Sedwood City, CA \\
\hline Verifi $^{\mathrm{TM}}$ & Verinata Health, now Illumina & San Jose, CA \\
\hline Harmony $^{\mathrm{TM}}$ & Ariosa Diagnostics & San Carlos, CA \\
\hline Panorama $^{\mathrm{TM}}$ & Natera & \\
\hline
\end{tabular}


for aneuploidies relied on FMF standards [29]. If the risk for aneuploidy was high ( $>1: 250)$, invasive diagnostic testing was carried out followed by karyotyping. The expenses were covered by health insurance. According to the recommendations published in 2017, the analysis of circulating cell-free DNA is recommended to women at high risk (from $1: 1,000$ to $1: 51$ ) for fetal trisomy 21 revealed by 1st trimester ultrasound and biochemistry screening. Pregnant women whose risk for aneuploidy is 1:50 or higher should undergo an invasive diagnostic procedure but still can opt for molecular screening first. It is emphasized that NIPT should not be regarded as a substitute for invasive diagnostic testing. The guidelines outline the need for developing a quality control and lab accreditation system. The screening strategy is to be revised in 3 years; among other things, the revision will cover the issues of screening for other aneuploidies and microdeletions.

\section{USA}

About 6.35 million pregnancies are reported annually in the USA. The NIPT market is divided between a few major players (see the Table) [86].

NIPT expenses are covered by health insurance or a patient's personal funds. No funding is received from the state.

So far, 4 medical associations have proposed guidelines for NIPT:

- the American College of Obstetricians and Gynecologists (ACOG), May 2016 [87];

- the International Society for Prenatal Diagnosis, April 2015 [80];

- the National society of Genetic Counselors, October 2016 [88];

- the American College of Medical Genetics and Genomics (ACMG) [89].

The ACMG notes that the evolution of NIPT methods and techniques is so rapid that any currently existing clinical recommendations will become obsolete in just a couple of years. Similar to ACOG, the ACMG guidelines emphasize that all pregnant women should be informed about the possibility of undergoing NIPT and its relative advantages over conventional screening for trisomies 13, 18 and 21. Some experts and manufacturers consider these guidelines as a signal for ordering NIPT for all pregnant women regardless of the results of 1st trimester screening. This interpretation is wrong. ACMG only recommends that pregnant women should be informed of the possibility of undergoing NIPT and provided with all relevant information about the test [86]. Unfortunately, many physicians are unaware of NIPT limitations, tend to misinterpret its results or take wrong decisions. Knowing that, NIPT manufacturers provide their own genetic counseling, which raises a number of questions since the counsellors involved can be biased.
Recently, there has been a rise in the number of patients who test false-positive for sex chromosome aneuploidies. It is imperative that patients should be informed of the situation and explained that clinical outcomes for children with such aneuploidies vary. For example, although the XO karyotype is a common cause of pregnancy loss, the quality of life of women with Turner syndrome is relatively high.

The guidelines stress that NIPT results should provide accurate information about NIPT specificity, sensitivity, PPV, NPV, and fetal DNA fraction for all types of analyzed mutations (aneuploidies of autosomes, sex chromosomes, CNV).

The most common cause of NIPT failure is low fetal DNA fraction. The low fDNA fraction correlates with a number of fetal aneuploidies [62, 72], meaning that in the case of NIPT failure, the patient should be immediately offered to undergo an invasive diagnostic test instead of repeating NIPT. ACMG does not recommend to use NIPT for detecting microdeletions because no reliable assessment of its specificity and sensitivity has been made so far.

\section{Russia}

In Russia, the number of annually reported pregnancies is about 1.8 million. Screening for genetic pathology of the fetus includes biochemistry tests and ultrasound examinations conducted in the 1st trimester. If the revealed risk is $1: 100$, the woman is offered to consult a geneticist and undergo an invasive diagnostic test. All expenses are covered by health insurance and regional budgets [90]. Clinical recommendations on NIPT were published in 2016 [91]; they are largely consistent with the ACMG guidelines mentioned above.

A few obstacles impede NIPT promotion on the Russian market: NIPT is not certified in Russia and almost all MPS reagents and equipment have no marketing authorization in our country.

\section{CONCLUSION}

Incorporation of NIPT into clinical practice poses a serious dilemma. If we raise the risk threshold signaling the need for NIPT to a higher value, the doctors who perform invasive testing may lose their skills due to the lack of clients, which will lead to diagnostic inaccuracy. In this case, the detection rate may even become lower than it is now. If we start to offer NIPT to every pregnant woman, the total expenses will soar and become unacceptable even for the most affluent and developed countries. This means that the optimum risk value should be defined at which the balance between the aneuploidy detection rate and the incurred costs will be harmonious.

\section{References}

1. Hassold $\mathrm{T}$, Hall H, Hunt P. The origin of human aneuploidy: where we have been, where we are going. Human molecular genetics. 2007; 16 (2): 203-8.

2. Driscoll DA, Gross S. Prenatal screening for aneuploidy. New England Journal of Medicine. 2009; 360 (24): 2556-62.

3. Nagaoka SI, Hassold TJ, Hunt PA. Human aneuploidy: mechanisms and new insights into an age-old problem. Nature Reviews Genetics. 2012; 13 (7): 493-504.

4. Ehrich M, Deciu C, Zwiefelhofer T, Tynan JA, Cagasan L, Tim R, et al. Noninvasive detection of fetal trisomy 21 by sequencing of DNA in maternal blood: a study in a clinical setting. American journal of obstetrics and gynecology. 2011; 204 (3): 205-e1.
5. Morris JK, Mutton DE, Alberman E. Revised estimates of the maternal age specific live birth prevalence of Down's syndrome. Journal of medical screening. 2002; 9 (1): 2-6.

6. Buckley F, Buckley S. Wrongful deaths and rightful lives-screening for Down syndrome. Down Syndrome Research and Practice. 2008; 12 (2): 79-86.

7. Wald NJ, Hackshaw AK. Combining ultrasound and biochemistry in first-trimester screening for Down's syndrome. Prenatal diagnosis. 1997; 17 (9): 821-9.

8. Sillence KA, Madgett TE, Roberts LA, Overton TG, Avent ND. Non-invasive screening tools for Down's syndrome: a review. Diagnostics. 2013; 3 (2): 291-314. 
9. Choy KW, Kwok YK, Cheng YKY, Wong KM, Wong HK, Leung KO, et al. Diagnostic accuracy of the BACs-on-Beads ${ }^{\mathrm{TM}}$ assay versus karyotyping for prenatal detection of chromosomal abnormalities: a retrospective consecutive case series. BJOG: An International Journal of Obstetrics \& Gynaecology. 2014; 121 (10): 1245-52.

10. Lo YD, Corbetta N, Chamberlain PF, Rai V, Sargent IL, Redman CW, et al. Presence of fetal DNA in maternal plasma and serum. The lancet. 1997; 350 (9076): 485-7.

11. Lo YD, Hjelm NM, Fidler C, Sargent IL, Murphy MF, Chamberlain PF, et al. Prenatal diagnosis of fetal RhD status by molecular analysis of maternal plasma. New England Journal of Medicine. 1998; 339 (24): 1734-8.

12. Farina A, Caramelli E, Concu M, Sekizawa A, Ruggeri R, Bovicelli L, et al. Testing normality of fetal DNA concentration in maternal plasma at 10-12 completed weeks' gestation: a preliminary approach to a new marker for genetic screening. Prenatal Diagnosis: Published in Affiliation With the International Society for Prenatal Diagnosis. 2002; 22 (2): 148-52.

13. Bischoff FZ, Lewis DE, Simpson JL. Cell-free fetal DNA in maternal blood: kinetics, source and structure. Human reproduction update. 2005; 11 (1): 59-67.

14. Wang E, Batey A, Struble C, Musci T, Song K, Oliphant A. Gestational age and maternal weight effects on fetal cell-free DNA in maternal plasma. Prenatal diagnosis. 2013; 33 (7): 662-6.

15. Curnow KJ, Gross SJ, Hall MP, Stosic M, Demko Z, Zimmermann B, et al. Clinical experience and follow-up with large scale singlenucleotide polymorphism-based noninvasive prenatal aneuploidy testing. American journal of obstetrics and gynecology. 2014; 211 (5): 527-e1.

16. Tjoa ML, Cindrova-Davies T, Spasic-Boskovic O, Bianchi DW, Burton GJ. Trophoblastic oxidative stress and the release of cellfree feto-placental DNA. The American journal of pathology. 2006: 169 (2): 400-4

17. Alberry M, Maddocks $\mathrm{D}$, Jones $\mathrm{M}$, Abdel Hadi M, Abdel-Fattah $\mathrm{S}$, Avent N, Soothill PW. Free fetal DNA in maternal plasma in anembryonic pregnancies: confirmation that the origin is the trophoblast. Prenatal Diagnosis: Published in Affiliation With the International Society for Prenatal Diagnosis. 2007; 27 (5): 415-8.

18. Gardner RM, Sutherland GR, Shaffer LG. Chromosome abnormalities and genetic counseling. Oxford University Press USA. 2011; (61).

19. Lo YD, Chan KA, Sun H, Chen EZ, Jiang P, Lun FM, et al. Maternal plasma DNA sequencing reveals the genome-wide genetic and mutational profile of the fetus. Science translational medicine. 2010; 2 (61): 61ra91-61ra91.

20. Ivanov M, Baranova A, Butler T, Spellman P, Mileyko V. Nonrandom fragmentation patterns in circulating cell-free DNA reflect epigenetic regulation. BMC genomics. 2015; 16 (13): S1.

21. Sancho M, Diani E, Beato M, Jordan A. Depletion of human histone $\mathrm{H} 1$ variants uncovers specific roles in gene expression and cell growth. PLoS genetics. 2008; 4 (10): e1000227.

22. Jiang P, Lo YMD. The long and short of circulating cell-free DNA and the ins and outs of molecular diagnostics. Trends in Genetics. 2016; 32 (6): 360-71.

23. Geiman TM, Muegge K. DNA methylation in early development. Molecular Reproduction and Development: Incorporating Gamete Research. 2010; 77 (2): 105-13.

24. Sun $\mathrm{K}$, et al. Plasma DNA tissue mapping by genome-wide methylation sequencing for noninvasive prenatal, cancer, and transplantation assessments. Proceedings of the National Academy of Sciences. 2015; 112 (40): E5503-E5512.

25. Sun $\mathrm{K}$, Jiang $\mathrm{P}$, Wong $\mathrm{Al}$, Cheng $\mathrm{YK}$, Cheng $\mathrm{SH}$, Zhang $\mathrm{H}$, et al Size-tagged preferred ends in maternal plasma DNA shed light on the production mechanism and show utility in noninvasive prenatal testing. Proceedings of the National Academy of Sciences. 2018; 115 (22): E5106-E5114

26. Tamminga S, van Maarle M, Henneman L, Oudejans CB, Cornel MC, Sistermans EA. Maternal plasma DNA and RNA sequencing for prenatal testing. Advances in clinical chemistry. 2016; (74): 63-102.

27. Ashoor G, Poon L, Syngelaki A, Mosimann B, Nicolaides KH. Fetal fraction in maternal plasma cell-free DNA at 11-13 weeks' gestation: effect of maternal and fetal factors. Fetal diagnosis and therapy. 2012; 31 (4): 237-43.
28. Canick JA, et al. The impact of maternal plasma DNA fetal fraction on next generation sequencing tests for common fetal aneuploidies. Prenatal diagnosis. 2013; 33 (7): 667-74.

29. Wright D, Syngelaki A, Bradbury I, Akolekar R, Nicolaides KH. First-trimester screening for trisomies 21,18 and 13 by ultrasound and biochemical testing. Fetal diagnosis and therapy. 2014; 35 (2): 118-26.

30. Kim SK, Hannum G, Geis J, Tynan J, Hogg G, Zhao C, et al. Determination of fetal DNA fraction from the plasma of pregnant women using sequence read counts. Prenatal diagnosis. 2015; 35 (8): 810-15

31. Jiang $P$, Peng $X$, Su $X$, Sun $K$, Stephanie CY, Chu Wl, et al, FetalQuant SD: accurate quantification of fetal DNA fraction by shallow-depth sequencing of maternal plasma DNA. NPJ genomic medicine. 2016; (1): 16013.

32. Peng $X L$, Jiang $P$. Bioinformatics approaches for fetal DNA fraction estimation in noninvasive prenatal testing. International journal of molecular sciences. 2017; 18 (2): 453

33. Zimmermann B, Hill M, Gemelos G, Demko Z, Banjevic M, Baner J, et al. Noninvasive prenatal aneuploidy testing of chromosomes $13,18,21, X$, and $Y$, using targeted sequencing of polymorphic loci. Prenatal diagnosis. 2012; 32 (13): 1233-41.

34. Lun FM, Chiu RW, Sun K, Leung TY, Jiang P, Chan KA, et al Noninvasive prenatal methylomic analysis by genomewide bisulfite sequencing of maternal plasma DNA. Clinical chemistry. DOI: 10.1373/clinchem.2013.212274.

35. Yu SC, et al. Size-based molecular diagnostics using plasma DNA for noninvasive prenatal testing. Proceedings of the National Academy of Sciences. 2014; 111 (23): 8583-8.

36. Cirigliano V, Ordoñez E, Rueda L, Syngelaki A, Nicolaides KH. Performance of the neoBona test: a new paired-end massively parallel shotgun sequencing approach for cell-free DNA-based aneuploidy screening. Ultrasound in Obstetrics \& Gynecology. 2017; 49 (4): 460-4.

37. Straver R, Oudejans C, Sistermans EA, Reinders MJ. Calculating the fetal fraction for noninvasive prenatal testing based on genome-wide nucleosome profiles. Prenatal diagnosis. 2016; 36 (7): 614-21.

38. Kim SK, Hannum G, Geis J, Tynan J, Hogg G, Zhao C, Boom D. Determination of fetal DNA fraction from the plasma of pregnant women using sequence read counts. Prenatal diagnosis. 2015; 35 (8): 810-5.

39. Chen S, Lau TK, Zhang C, Xu C, Xu Z, Hu P, et al. A method for noninvasive detection of fetal large deletions/duplications by low coverage massively parallel sequencing. Prenatal diagnosis. 2013; 33 (6): 584-90.

40. Van den Veyver IB. Recent advances in prenatal genetic screening and testing. F1000 Research. 2016; 5 (F1000 Faculty Rev): 2591.

41. Peters D, Chu T, Yatsenko SA, Hendrix N, Hogge WA, Surti U, et al. Noninvasive prenatal diagnosis of a fetal microdeletion syndrome. New England Journal of Medicine. 2011; 365 (19): 1847-8.

42. Jensen TJ, Dzakula Z, Deciu C, van den Boom D, Ehrich M. Detection of microdeletion 22q11. 2 in a fetus by next-generation sequencing of maternal plasma. Clinical chemistry. 2012; 58 (7): 1148-51.

43. Srinivasan A, Bianchi DW, Huang $H$, Sehnert AJ, Rava RP. Noninvasive detection of fetal subchromosome abnormalities via deep sequencing of maternal plasma. The American Journal of Human Genetics. 2013; 92 (2): 167-76.

44. Lefkowitz RB, Tynan JA, Liu T, Wu Y, Mazloom AR, Almasri E, et al. Clinical validation of a noninvasive prenatal test for genomewide detection of fetal copy number variants. American journal of obstetrics and gynecology. 2016; 215 (2): 227-e1.

45. Straver R, Sistermans EA, Holstege H, Visser A, Oudejans CB, Reinders MJ. WISECONDOR: detection of fetal aberrations from shallow sequencing maternal plasma based on a within-sample comparison scheme. Nucleic acids research. 2013; 42 (5): e31-e31.

46. Zhao C, Tynan J, Ehrich M, Hannum G, McCullough R, Saldivar JS, Deciu C. Detection of fetal subchromosomal abnormalities by sequencing circulating cell-free DNA from maternal plasma. Clinical chemistry. 2015.

47. Nicolaides KH, Syngelaki A, Gil M, Atanasova V, Markova D. Validation of targeted sequencing of single-nucleotide 
polymorphisms for non-invasive prenatal detection of aneuploidy of chromosomes 13, 18, 21, X, and Y. Prenatal diagnosis. 2013; 33 (6): 575-9.

48. Wapner RJ, Babiarz JE, Levy B, Stosic M, Zimmermann B, Sigurjonsson S, Hu J. Expanding the scope of noninvasive prenatal testing: detection of fetal microdeletion syndromes. American journal of obstetrics and gynecology. 2015; 212 (3): 332-e1.

49. Costa JM, Benachi A, Gautier E. New strategy for prenata diagnosis of X-linked disorders. New England Journal of Medicine. 2002; 346 (19): 1502.

50. Lo YD, Hjelm NM, Fidler C, Sargent IL, Murphy MF, Chamberlain PF et al. Prenatal diagnosis of fetal RhD status by molecular analysis of maternal plasma. New England Journal of Medicine. 1998; 339 (24): 1734-8

51. Tang NL, Leung TN, Zhang J, Lau TK, Lo YD. Detection of fetalderived paternally inherited X-chromosome polymorphisms in maternal plasma. Clinical chemistry. 1999; 45 (11): 2033-5.

52. Bustamante-Aragonés A, de Alba MR, Perlado S, Trujillo-Tiebas MJ, Arranz JP, Díaz-Recasens J, et al. Non-invasive prenatal diagnosis of single-gene disorders from maternal blood. Gene. 2012; 504 (1): 144-9.

53. Amicucci P, Gennarelli M, Novelli G, Dallapiccola B. Prenatal diagnosis of myotonic dystrophy using fetal DNA obtained from maternal plasma. Clinical chemistry. 2000; 46 (2): 301-2.

54. Vermeulen C, Geeven G, de Wit E, Verstegen MJ, Jansen RP, van Kranenburg $M$, et al. Sensitive monogenic noninvasive prenatal diagnosis by targeted haplotyping. The American Journal of Human Genetics. 2017; 101 (3): 326-39.

55. Tong YK, Jin S, Chiu RW, Ding C, Chan KA, Leung TY, et al Noninvasive prenatal detection of trisomy 21 by an epigeneticgenetic chromosome-dosage approach. Clinical chemistry. 2010; 56 (1): $90-8$

56. Tsui DW, Lam YD, Lee WS, Leung TY, Lau TK, Lau ET, et al. Systematic identification of placental epigenetic signatures for the noninvasive prenatal detection of Edwards syndrome. PloS one. 2010; 5 (11): e15069.

57. Yuen RK, Penaherrera MS, Von Dadelszen P, McFadden DE, Robinson WP. DNA methylation profiling of human placentas reveals promoter hypomethylation of multiple genes in early-onset preeclampsia. European Journal of Human Genetics. 2010; 18 (9): 1006

58. Blair JD, Yuen RK, Lim BK, McFadden DE, von Dadelszen P, Robinson WP. Widespread DNA hypomethylation at gene enhancer regions in placentas associated with early-onset preeclampsia. Molecular human reproduction. 2013; 19 (10): 697-708.

59. Chu T, Bunce K, Shaw P, Shridhar V, Althouse A, Hubel C et al. Comprehensive analysis of preeclampsia-associated DNA methylation in the placenta. PLoS One. 2014; 9 (9): e107318.

60. Hahn S, Rusterholz C, Hösli I, Lapaire O. Cell-free nucleic acids as potential markers for preeclampsia. Placenta. 2011; (32): S17-S20.

61. Bianchi DW, Parker RL, Wentworth J, Madankumar R, Saffer C Das $A F$, et al. DNA sequencing versus standard prenatal aneuploidy screening. New England journal of medicine. 2014; 370 (9): 799-808.

62. Norton ME, Jacobsson B, Swamy GK, Laurent LC, Ranzini AC Brar $\mathrm{H}$, et al. Cell-free DNA analysis for noninvasive examination of trisomy. New England Journal of Medicine. 2015; 372 (17): 1589-97.

63. Wataganara T, Peter I, Messerlian GM, Borgatta L, Bianchi DW. Inverse correlation between maternal weight and second trimester circulating cell-free fetal DNA levels. Obstetrics \& Gynecology. 2004; 104 (3): 545-50.

64. Rumyantsev AG, Kurcer MA, Mareeva JM, Misjurin AV, Roumiantsev SA, Ustjugov AJ. Clinical significance of the fetal microchimerism for mother. Cellular Transplantation \& Tissue Engineering. 2012; 7 (2): 103-111.

65. Wang $Y$, et al. Maternal mosaicism is a significant contributor to discordant sex chromosomal aneuploidies associated with noninvasive prenatal testing. Clinical chemistry. 2014; 60 (1): 251-9.

66. Bianchi DW. Cherchez la femme: maternal incidental findings can explain discordant prenatal cell-free DNA sequencing results. Genetics in Medicine. 2017; DOI: 10.1038/gim.2017.219.
67. Hartwig TS, Ambye L, Sørensen S, Jørgensen FS. Discordant non-invasive prenatal testing (NIPT)-a systematic review. Prenatal diagnosis. 2017; 37 (6): 527-39.

68. Attilakos G, Maddocks DG, Davies T, Hunt LP, Avent ND, Soothill PW, et al. Quantification of free fetal DNA in multiple pregnancies and relationship with chorionicity. Prenatal diagnosis. 2011; 31 (10): 967-72.

69. Bevilacqua E, Gil MM, Nicolaides KH, Ordoñez E, Cirigliano V, Dierickx H, et al. Performance of screening for aneuploidies by cell-free DNA analysis of maternal blood in twin pregnancies. Ultrasound in Obstetrics \& Gynecology. 2015; 45 (1): 61-6.

70. Curnow KJ, Wilkins-Haug L, Ryan A, Kırkızlar E, Stosic M, Hall MP, et al. Detection of triploid, molar, and vanishing twin pregnancies by a single-nucleotide polymorphism-based noninvasive prenatal test. American journal of obstetrics and gynecology. 2015; 212 (1): 79-e1.

71. Gil MM, Quezada MS, Revello R, Akolekar R, Nicolaides KH. Analysis of cell-free DNA in maternal blood in screening for fetal aneuploidies: updated meta-analysis. Ultrasound in obstetrics \& gynecology. 2015; 45 (3): 249-66.

72. Zhang $H$, Gao $Y$, Jiang $F$, Fu M, Yuan $Y$, Guo $Y$, et al. Noninvasive prenatal testing for trisomies 21, 18 and 13: clinical experience from 146958 pregnancies. Ultrasound in Obstetrics \& Gynecology. 2015; 45 (5): 530-8.

73. Russell LM, Strike P, Browne CE, Jacobs PA. X chromosome loss and ageing. Cytogenetic and genome research. 2007; 116 (3): $181-5$.

74. Samango-Sprouse C, Kırkızlar E, Hall MP, Lawson P, Demko Z, Zneimer SM, et al. Incidence of $X$ and $Y$ chromosomal aneuploidy in a large child bearing population. PloS One. 2016; 11 (8): e0161045.

75. Shubina J, Trofimov DY, Barkov IY, Stupko OK, Goltsov AY, Mukosey IS, et al. In silico size selection is effective in reducing false positive NIPS cases of monosomy $X$ that are due to maternal mosaic monosomy X. Prenatal diagnosis. 2017; 37 (13): 1305-10.

76. Bianchi DW, Chudova D, Sehnert AJ, Bhatt S, Murray K, Prosen TL, et al. Noninvasive prenatal testing and incidental detection of occult maternal malignancies. Jama. 2015; 314 (2): 162-9.

77. Ferguson-Smith MA. Placental mRNA in maternal plasma: prospects for fetal screening. Proceedings of the National Academy of Sciences. 2003; 100 (8): 4360-2.

78. Chiu RW, Cantor CR, Lo YD. Non-invasive prenatal diagnosis by single molecule counting technologies. Trends in genetics. 2009; 25 (7): 324-31.

79. ACOG Practice Bulletin \# 77: screening for fetal chromosomal abnormalities. Obstet Gynecol. 2007; (109): 217-27.

80. Benn P, Borrell A, Chiu RW, Cuckle H, Dugoff L, Faas B, et al. Position statement from the Chromosome Abnormality Screening Committee on behalf of the Board of the International Society for Prenatal Diagnosis. Prenatal diagnosis. 2015; 35 (8): 725-34.

81. Kascheeva TK, Kuznetzova TV, Baranov VS. New technologies and trends of prenatal diagnostics. Journal of obstetrics and woman disease. 2017; 66 (2): 33-39.

82. UK National Screening Committee. www.gov.uk URL. Available from: https://www.gov.uk/government/groups/uk-national-screeningcommittee-uk-nsc (data obrashhenija: 20.07.2018).

83. Screening in the UK: making effective recommendations 2015 to 2016. Public Health England hosts the UK National Screening Committee URL. Available from: https://assets. publishing.service.gov.uk/government/uploads/system/uploads/ attachment_data/file/538524/Screening_in_the_UK__making effective_recommendations_2015_to_2016_180716_final.pdf (data obrashhenija: 20.07.2018).

84. Analysis of foetal DNA in the woman's blood: non-invasive prenatal testing (NIPT) for trisomy 13, 18 and 21. SFOG Guidelines URL. Available from: http://www.nfog.org/files/guidelines/NIPT\%20 2016\%2006\%2005\%20.pdf (data obrashhenija: 20.07.2018).

85. Trisomie 21: la HAS actualise ses recommandations concernant le dépistage prénatal de la trisomie 21. www.has-sante.fr URL. Available from: https://www.has-sante.fr/portail/jcms/c_2768535/fr/ trisomie-21-la-has-actualise-ses-recommandations-concernant-ledepistage-prenatal-de-la-trisomie-21 (data obrashhenija: 20.07.2018).

86. Allyse M, Wick MJ. What do the new American College of Medical 
Genetics and Genomics (ACMG) guidelines mean for the provision of non-invasive prenatal genetic screening? Journal of Obstetrics and Gynaecology. 2017; 37 (6): 795-8.

87. American College of Obstetricians and Gynecologists: Screening for fetal aneuploidy. Obstet Gynecol. 2016; 127 (5): e123-137.

88. Prenatal cell-free DNA screening. National Society of Genetic Counselors. Available from: http://www.nsgc.org/p/bl/et/ blogaid=805\#.WCTELTNRftw.linkedin

89. Gregg AR, Skotko BG, Benkendorf JL, Monaghan KG, Bajaj K, Best RG, et al. Noninvasive prenatal screening for fetal aneuploidy, 2016 update: a position statement of the American College of
Medical Genetics and Genomics. Genetics in medicine. 2016; 18 (10): 1056-65.

90. Informacionno-metodicheskoe pis'mo Minzdrava RF ot 19.03.2015 \# 15-4/607. Available from: http://www.consultant. ru/document/cons_doc_LAW_177689/.

91. Sukhikh GT, Trofimov DYu, Barkov IYu, Donnikov AE, Shubina ES, Korostin DO, et al. Non-invasive prenatal DNA-screening of fetus aneuploidies using maternal blood based on high-throuhgput sequencing. Clinical recommendations. Obstetrics and gynecology. 2016; (6): 3-22.

\section{Литература}

1. Hassold T, Hall H, Hunt P. The origin of human aneuploidy: where we have been, where we are going. Human molecular genetics. 2007; 16 (2): 203-8.

2. Driscoll DA, Gross S. Prenatal screening for aneuploidy. New England Journal of Medicine. 2009; 360 (24): 2556-62.

3. Nagaoka SI, Hassold TJ, Hunt PA. Human aneuploidy: mechanisms and new insights into an age-old problem. Nature Reviews Genetics. 2012; 13 (7): 493-504.

4. Ehrich M, Deciu C, Zwiefelhofer T, Tynan JA, Cagasan L, Tim R et al. Noninvasive detection of fetal trisomy 21 by sequencing of DNA in maternal blood: a study in a clinical setting. American journal of obstetrics and gynecology. 2011; 204 (3): 205-e1.

5. Morris JK, Mutton DE, Alberman E. Revised estimates of the maternal age specific live birth prevalence of Down's syndrome. Journal of medical screening. 2002; 9 (1): 2-6.

6. Buckley F, Buckley S. Wrongful deaths and rightful lives-screening for Down syndrome. Down Syndrome Research and Practice. 2008; 12 (2): 79-86.

7. Wald NJ, Hackshaw AK. Combining ultrasound and biochemistry in first-trimester screening for Down's syndrome. Prenatal diagnosis. 1997; 17 (9): 821-9.

8. Sillence KA, Madgett TE, Roberts LA, Overton TG, Avent ND. Non-invasive screening tools for Down's syndrome: a review. Diagnostics. 2013; 3 (2): 291-314.

9. Choy KW, Kwok YK, Cheng YKY, Wong KM, Wong HK, Leung KO, et al. Diagnostic accuracy of the BACs-on-Beads ${ }^{\mathrm{TM}}$ assay versus karyotyping for prenatal detection of chromosomal abnormalities: a retrospective consecutive case series. BJOG: An International Journal of Obstetrics \& Gynaecology. 2014; 121 (10): 1245-52.

10. Lo YD, Corbetta N, Chamberlain PF, Rai V, Sargent IL, Redman CW et al. Presence of fetal DNA in maternal plasma and serum. The lancet. 1997; 350 (9076): 485-7.

11. Lo YD, Hjelm NM, Fidler C, Sargent IL, Murphy MF, Chamberlain PF, et al. Prenatal diagnosis of fetal RhD status by molecular analysis of maternal plasma. New England Journal of Medicine. 1998; 339 (24): $1734-8$

12. Farina A, Caramelli E, Concu M, Sekizawa A, Ruggeri R, Bovicelli L, et al. Testing normality of fetal DNA concentration in maternal plasma at 10-12 completed weeks' gestation: a preliminary approach to a new marker for genetic screening. Prenata Diagnosis: Published in Affiliation With the International Society for Prenatal Diagnosis. 2002; 22 (2): 148-52.

13. Bischoff FZ, Lewis DE, Simpson JL. Cell-free fetal DNA in materna blood: kinetics, source and structure. Human reproduction update. 2005; 11 (1): 59-67.

14. Wang E, Batey A, Struble C, Musci T, Song K, Oliphant A Gestational age and maternal weight effects on fetal cell-free DNA in maternal plasma. Prenatal diagnosis. 2013; 33 (7): 662-6.

15. Curnow KJ, Gross SJ, Hall MP, Stosic M, Demko Z, Zimmermann B et al. Clinical experience and follow-up with large scale singlenucleotide polymorphism-based noninvasive prenatal aneuploidy testing. American journal of obstetrics and gynecology. 2014; 211 (5): 527-e1.

16. Tjoa ML, Cindrova-Davies T, Spasic-Boskovic O, Bianchi DW, Burton GJ. Trophoblastic oxidative stress and the release of cellfree feto-placental DNA. The American journal of pathology. 2006; 169 (2): 400-4
17. Alberry M, Maddocks D, Jones M, Abdel Hadi M, Abdel-Fattah S, Avent N, Soothill PW. Free fetal DNA in maternal plasma in anembryonic pregnancies: confirmation that the origin is the trophoblast. Prenatal Diagnosis: Published in Affiliation With the International Society for Prenatal Diagnosis. 2007; 27 (5): 415-8.

18. Gardner RM, Sutherland GR, Shaffer LG. Chromosome abnormalities and genetic counseling. Oxford University Press USA. 2011; (61).

19. Lo YD, Chan KA, Sun H, Chen EZ, Jiang P, Lun FM, et al. Maternal plasma DNA sequencing reveals the genome-wide genetic and mutational profile of the fetus. Science translational medicine. 2010; 2 (61): 61ra91-61ra91.

20. Ivanov M, Baranova A, Butler T, Spellman P, Mileyko V. Nonrandom fragmentation patterns in circulating cell-free DNA reflect epigenetic regulation. BMC genomics. 2015; 16 (13): S1.

21. Sancho M, Diani E, Beato M, Jordan A. Depletion of human histone $\mathrm{H} 1$ variants uncovers specific roles in gene expression and cell growth. PLoS genetics. 2008; 4 (10): e1000227.

22. Jiang P, Lo YMD. The long and short of circulating cell-free DNA and the ins and outs of molecular diagnostics. Trends in Genetics. 2016; 32 (6): 360-71.

23. Geiman TM, Muegge K. DNA methylation in early development. Molecular Reproduction and Development: Incorporating Gamete Research. 2010; 77 (2): 105-13.

24. Sun $\mathrm{K}$, et al. Plasma DNA tissue mapping by genome-wide methylation sequencing for noninvasive prenatal, cancer, and transplantation assessments. Proceedings of the National Academy of Sciences. 2015; 112 (40): E5503-E5512.

25. Sun $\mathrm{K}$, Jiang $\mathrm{P}$, Wong $\mathrm{Al}$, Cheng $\mathrm{YK}$, Cheng $\mathrm{SH}$, Zhang $\mathrm{H}$, et al. Size-tagged preferred ends in maternal plasma DNA shed light on the production mechanism and show utility in noninvasive prenatal testing. Proceedings of the National Academy of Sciences. 2018; 115 (22): E5106-E5114.

26. Tamminga S, van Maarle M, Henneman L, Oudejans CB, Cornel MC Sistermans EA. Maternal plasma DNA and RNA sequencing for prenatal testing. Advances in clinical chemistry. 2016; (74): 63-102.

27. Ashoor G, Poon L, Syngelaki A, Mosimann B, Nicolaides KH. Fetal fraction in maternal plasma cell-free DNA at 11-13 weeks' gestation: effect of maternal and fetal factors. Fetal diagnosis and therapy. 2012; 31 (4): 237-43.

28. Canick JA, et al. The impact of maternal plasma DNA feta fraction on next generation sequencing tests for common fetal aneuploidies. Prenatal diagnosis. 2013; 33 (7): 667-74.

29. Wright D, Syngelaki A, Bradbury I, Akolekar R, Nicolaides $\mathrm{KH}$. First-trimester screening for trisomies 21,18 and 13 by ultrasound and biochemical testing. Fetal diagnosis and therapy. 2014; 35 (2): 118-26.

30. Kim SK, Hannum G, Geis J, Tynan J, Hogg G, Zhao C, et al Determination of fetal DNA fraction from the plasma of pregnant women using sequence read counts. Prenatal diagnosis. 2015; 35 (8): $810-15$

31. Jiang $P$, Peng $X$, Su $X$, Sun $K$, Stephanie CY, Chu Wl, et al. FetalQuant SD: accurate quantification of fetal DNA fraction by shallow-depth sequencing of maternal plasma DNA. NPJ genomic medicine. 2016; (1): 16013.

32. Peng $X L$, Jiang $P$. Bioinformatics approaches for fetal DNA fraction estimation in noninvasive prenatal testing. International journal of 
molecular sciences. 2017; 18 (2): 453

33. Zimmermann B, Hill M, Gemelos G, Demko Z, Banjevic M, Baner J, et al. Noninvasive prenatal aneuploidy testing of chromosomes $13,18,21, \mathrm{X}$, and $\mathrm{Y}$, using targeted sequencing of polymorphic loci. Prenatal diagnosis. 2012; 32 (13): 1233-41.

34. Lun FM, Chiu RW, Sun K, Leung TY, Jiang P, Chan KA, et al Noninvasive prenatal methylomic analysis by genomewide bisulfite sequencing of maternal plasma DNA. Clinical chemistry. DOI: 10.1373/clinchem.2013.212274

35. Yu SC, et al. Size-based molecular diagnostics using plasma DNA for noninvasive prenatal testing. Proceedings of the National Academy of Sciences. 2014; 111 (23): 8583-8.

36. Cirigliano V, Ordoñez E, Rueda L, Syngelaki A, Nicolaides $\mathrm{KH}$. Performance of the neoBona test: a new paired-end massively parallel shotgun sequencing approach for cell-free DNA-based aneuploidy screening. Ultrasound in Obstetrics \& Gynecology. 2017; 49 (4): 460-4.

37. Straver R, Oudejans C, Sistermans EA, Reinders MJ. Calculating the fetal fraction for noninvasive prenatal testing based on genome-wide nucleosome profiles. Prenatal diagnosis. 2016; 36 (7): 614-21.

38. Kim SK, Hannum G, Geis J, Tynan J, Hogg G, Zhao C, Boom D. Determination of fetal DNA fraction from the plasma of pregnant women using sequence read counts. Prenatal diagnosis. 2015; 35 (8): 810-5.

39. Chen S, Lau TK, Zhang C, Xu C, Xu Z, Hu P, et al. A method for noninvasive detection of fetal large deletions/duplications by low coverage massively parallel sequencing. Prenatal diagnosis. 2013; 33 (6): 584-90.

40. Van den Veyver IB. Recent advances in prenatal genetic screening and testing. F1000 Research. 2016; 5 (F1000 Faculty Rev): 2591

41. Peters D, Chu T, Yatsenko SA, Hendrix N, Hogge WA, Surti U, et al. Noninvasive prenatal diagnosis of a fetal microdeletion syndrome. New England Journal of Medicine. 2011; 365 (19): 1847-8.

42. Jensen TJ, Dzakula Z, Deciu C, van den Boom D, Ehrich M. Detection of microdeletion 22q11. 2 in a fetus by next-generation sequencing of maternal plasma. Clinical chemistry. 2012; 58 (7): 1148-51.

43. Srinivasan A, Bianchi DW, Huang $H$, Sehnert AJ, Rava RP. Noninvasive detection of fetal subchromosome abnormalities via deep sequencing of maternal plasma. The American Journal of Human Genetics. 2013; 92 (2): 167-76.

44. Lefkowitz RB, Tynan JA, Liu T, Wu Y, Mazloom AR, Almasri E, et al. Clinical validation of a noninvasive prenatal test for genomewide detection of fetal copy number variants. American journal of obstetrics and gynecology. 2016; 215 (2): 227-e1.

45. Straver R, Sistermans EA, Holstege H, Visser A, Oudejans CB, Reinders MJ. WISECONDOR: detection of fetal aberrations from shallow sequencing maternal plasma based on a within-sample comparison scheme. Nucleic acids research. 2013; 42 (5): e31-e31.

46. Zhao C, Tynan J, Ehrich M, Hannum G, McCullough R, Saldivar JS Deciu C. Detection of fetal subchromosomal abnormalities by sequencing circulating cell-free DNA from maternal plasma. Clinical chemistry. 2015

47. Nicolaides $\mathrm{KH}$, Syngelaki A, Gil M, Atanasova V, Markova D. Validation of targeted sequencing of single-nucleotide polymorphisms for non-invasive prenatal detection of aneuploidy of chromosomes 13, 18, 21, X, and Y. Prenatal diagnosis. 2013; 33 (6): 575-9.

48. Wapner RJ, Babiarz JE, Levy B, Stosic M, Zimmermann B, Sigurjonsson S, Hu J. Expanding the scope of noninvasive prenata testing: detection of fetal microdeletion syndromes. American journal of obstetrics and gynecology. 2015; 212 (3): 332-e1.

49. Costa JM, Benachi A, Gautier E. New strategy for prenatal diagnosis of X-linked disorders. New England Journal of Medicine. 2002; 346 (19): 1502.

50. Lo YD, Hjelm NM, Fidler C, Sargent IL, Murphy MF, Chamberlain PF, et al. Prenatal diagnosis of fetal RhD status by molecular analysis of maternal plasma. New England Journal of Medicine. 1998; 339 (24): 1734-8.

51. Tang NL, Leung TN, Zhang J, Lau TK, Lo YD. Detection of fetalderived paternally inherited X-chromosome polymorphisms in maternal plasma. Clinical chemistry. 1999; 45 (11): 2033-5.
52. Bustamante-Aragonés A, de Alba MR, Perlado S, Trujillo-Tiebas MJ, Arranz JP, Díaz-Recasens J, et al. Non-invasive prenatal diagnosis of single-gene disorders from maternal blood. Gene. 2012; 504 (1): 144-9.

53. Amicucci P, Gennarelli M, Novelli G, Dallapiccola B. Prenatal diagnosis of myotonic dystrophy using fetal DNA obtained from maternal plasma. Clinical chemistry. 2000; 46 (2): 301-2.

54. Vermeulen C, Geeven G, de Wit E, Verstegen MJ, Jansen RP, van Kranenburg $M$, et al. Sensitive monogenic noninvasive prenatal diagnosis by targeted haplotyping. The American Journal of Human Genetics. 2017; 101 (3): 326-39.

55. Tong YK, Jin S, Chiu RW, Ding C, Chan KA, Leung TY, et al. Noninvasive prenatal detection of trisomy 21 by an epigeneticgenetic chromosome-dosage approach. Clinical chemistry. 2010; 56 (1): 90-8.

56. Tsui DW, Lam YD, Lee WS, Leung TY, Lau TK, Lau ET, et al. Systematic identification of placental epigenetic signatures for the noninvasive prenatal detection of Edwards syndrome. PloS one. 2010; 5 (11): e15069.

57. Yuen RK, Penaherrera MS, Von Dadelszen P, McFadden DE, Robinson WP. DNA methylation profiling of human placentas reveals promoter hypomethylation of multiple genes in early-onset preeclampsia. European Journal of Human Genetics. 2010; 18 (9): 1006.

58. Blair JD, Yuen RK, Lim BK, McFadden DE, von Dadelszen P, Robinson WP. Widespread DNA hypomethylation at gene enhancer regions in placentas associated with early-onset preeclampsia. Molecular human reproduction. 2013; 19 (10): 697-708.

59. Chu T, Bunce K, Shaw P, Shridhar V, Althouse A, Hubel C, et al. Comprehensive analysis of preeclampsia-associated DNA methylation in the placenta. PLoS One. 2014; 9 (9): e107318.

60. Hahn S, Rusterholz C, Hösli I, Lapaire O. Cell-free nucleic acids as potential markers for preeclampsia. Placenta. 2011; (32): S17-S20.

61. Bianchi DW, Parker RL, Wentworth J, Madankumar R, Saffer C, Das $A F$, et al. DNA sequencing versus standard prenatal aneuploidy screening. New England journal of medicine. 2014; 370 (9): 799-808.

62. Norton ME, Jacobsson B, Swamy GK, Laurent LC, Ranzini AC, Brar $\mathrm{H}$, et al. Cell-free DNA analysis for noninvasive examination of trisomy. New England Journal of Medicine. 2015; 372 (17): 1589-97.

63. Wataganara T, Peter I, Messerlian GM, Borgatta L, Bianchi DW. Inverse correlation between maternal weight and second trimester circulating cell-free fetal DNA levels. Obstetrics \& Gynecology. 2004; 104 (3): 545-50.

64. Румянцев А. Г., Курцер М. А., Мареева Ю. М., Мисюрин А. В., Румянцев С. А., Устюгов А. Ю. Клиническое значение фетального микрохимеризма у матери. Гены и клетки. 2012; 7 (2): 103-111.

65. Wang $\mathrm{Y}$, et al. Maternal mosaicism is a significant contributor to discordant sex chromosomal aneuploidies associated with noninvasive prenatal testing. Clinical chemistry. 2014; 60 (1): 251-9.

66. Bianchi DW. Cherchez la femme: maternal incidental findings can explain discordant prenatal cell-free DNA sequencing results. Genetics in Medicine. 2017; DOI: 10.1038/gim.2017.219.

67. Hartwig TS, Ambye L, Sørensen S, Jørgensen FS. Discordant non-invasive prenatal testing (NIPT)-a systematic review. Prenatal diagnosis. 2017; 37 (6): 527-39.

68. Attilakos G, Maddocks DG, Davies T, Hunt LP, Avent ND, Soothill PW, et al. Quantification of free fetal DNA in multiple pregnancies and relationship with chorionicity. Prenatal diagnosis. 2011; 31 (10): 967-72.

69. Bevilacqua E, Gil MM, Nicolaides KH, Ordoñez E, Cirigliano V, Dierick $\mathrm{H}$, et al. Performance of screening for aneuploidies by cell-free DNA analysis of maternal blood in twin pregnancies. Ultrasound in Obstetrics \& Gynecology. 2015; 45 (1): 61-6.

70. Curnow KJ, Wilkins-Haug L, Ryan A, Kırkızlar E, Stosic M, Hall MP, et al. Detection of triploid, molar, and vanishing twin pregnancies by a single-nucleotide polymorphism-based noninvasive prenatal test. American journal of obstetrics and gynecology. 2015; 212 (1): 79-e1.

71. Gil MM, Quezada MS, Revello R, Akolekar R, Nicolaides KH. Analysis of cell-free DNA in maternal blood in screening for fetal 
aneuploidies: updated meta-analysis. Ultrasound in obstetrics \& gynecology. 2015; 45 (3): 249-66.

72. Zhang $H$, Gao $Y$, Jiang $F$, Fu M, Yuan $Y$, Guo $Y$, et al. Noninvasive prenatal testing for trisomies 21, 18 and 13: clinical experience from 146958 pregnancies. Ultrasound in Obstetrics \& Gynecology. 2015; 45 (5): 530-8.

73. Russell LM, Strike P, Browne CE, Jacobs PA. X chromosome loss and ageing. Cytogenetic and genome research. 2007; 116 (3): 181-5.

74. Samango-Sprouse C, Kırkızlar E, Hall MP, Lawson P, Demko Z, Zneimer SM, et al. Incidence of $X$ and $Y$ chromosomal aneuploidy in a large child bearing population. PloS One. 2016; 11 (8): e0161045.

75. Shubina J, Trofimov DY, Barkov IY, Stupko OK, Goltsov AY, Mukosey IS, et al. In silico size selection is effective in reducing false positive NIPS cases of monosomy $X$ that are due to maternal mosaic monosomy X. Prenatal diagnosis. 2017; 37 (13): 1305-10.

76. Bianchi DW, Chudova D, Sehnert AJ, Bhatt S, Murray K, Prosen TL, et al. Noninvasive prenatal testing and incidental detection of occult maternal malignancies. Jama. 2015; 314 (2): 162-9.

77. Ferguson-Smith MA. Placental mRNA in maternal plasma: prospects for fetal screening. Proceedings of the National Academy of Sciences. 2003; 100 (8): 4360-2.

78. Chiu RW, Cantor CR, Lo YD. Non-invasive prenatal diagnosis by single molecule counting technologies. Trends in genetics. 2009; 25 (7): 324-31.

79. ACOG Practice Bulletin № 77: screening for fetal chromosomal abnormalities. Obstet Gynecol. 2007; (109): 217-27.

80. Benn P, Borrell A, Chiu RW, Cuckle H, Dugoff L, Faas B, et al. Position statement from the Chromosome Abnormality Screening Committee on behalf of the Board of the International Society for Prenatal Diagnosis. Prenatal diagnosis. 2015; 35 (8): 725-34.

81. Кащеева Т. К., Кузнецова Т. В., Баранов В. С. Новые технологии и тенденции развития пренатальной диагностики. Журнал акушерства и женских болезней. 2017; 66 (2): 33-39.

82. UK National Screening Committee. www.gov.uk URL. Available from: https://www.gov.uk/government/groups/uk-national-screeningcommittee-uk-nsc (дата обращения: 20.07.2018).

83. Screening in the UK: making effective recommendations
2015 to 2016. Public Health England hosts the UK National Screening Committee URL. Available from: https://assets. publishing.service.gov.uk/government/uploads/system/uploads/ attachment data/file/538524/Screening in the UK making effective_recommendations_2015_to_2016_180716_final.pdf (дата обращения: 20.07.2018).

84. Analysis of foetal DNA in the woman's blood: non-invasive prenatal testing (NIPT) for trisomy 13, 18 and 21. SFOG Guidelines URL: http://www.nfog.org/files/guidelines/NIPT\%202016\%2006\%20 05\%20.pdf (дата обращения: 20.07.2018).

85. Trisomie 21: la HAS actualise ses recommandations concernant le dépistage prénatal de la trisomie 21. www.has-sante.fr URL. Available from: https://www.has-sante.fr/portail/jcms/c_2768535/fr/ trisomie-21-la-has-actualise-ses-recommandations-concernant-ledepistage-prenatal-de-la-trisomie-21 (дата обращения: 20.07.2018).

86. Allyse M, Wick MJ. What do the new American College of Medical Genetics and Genomics (ACMG) guidelines mean for the provision of non-invasive prenatal genetic screening? Journal of Obstetrics and Gynaecology. 2017; 37 (6): 795-8.

87. American College of Obstetricians and Gynecologists: Screening for fetal aneuploidy. Obstet Gynecol. 2016; 127 (5): e123-137.

88. Prenatal cell-free DNA screening. National Society of Genetic Counselors. Available from: http://www.nsgc.org/p/bl/et/ blogaid=805\#.WCTELTNR ftw.linkedin.

89. Gregg AR, Skotko BG, Benkendorf JL, Monaghan KG, Bajaj K, Best RG, et al. Noninvasive prenatal screening for fetal aneuploidy, 2016 update: a position statement of the American College of Medical Genetics and Genomics. Genetics in medicine. 2016; 18 (10): 1056-65.

90. Информационно-методическое письмо Минздрава РФ от 19.03.2015 № 15-4/607. Доступно по ссылке: http://www. consultant.ru/document/cons_doc_LAW_177689/.

91. Сухих Г. Т., Трофимов Д. Ю, Барков И. Ю., Донников А. Е., Шубина Е. С., Коростин Д. О. и др. Неинвазивный пренатальный ДНК-скрининг анеуплоидий плода по крови матери методом высокопроизводительного секвенирования. Клинические рекомендации. Акушерство и гинекология. 2016; (6): 3-22. 